\title{
Malignant Childhood Germ Cell Tumor
}

National Cancer Institute

\section{Source}

National Cancer Institute. Malignant Childhood Germ Cell Tumor. NCI Thesaurus. Code C6541.

A malignant germ cell tumor that occurs during childhood. 